\title{
EFFECTS OF WEARING AN ANKLE BRACE ON GROUND REACTION FORCES DURING JUMPS IN BASKETBALL GAME SIMULATION
}

\author{
EFEITOS DO USO DE ÓRTESE DE TORNOZELO SOBRE AS FORÇAS DEREAÇÃO DO SOLO DURANTE SALTOS \\ EM SIMULAÇÃO DO JOGO DE BASQUETEBOL
}

\begin{abstract}
EFECTOS DEL USO DE ÓRTESIS DE TOBILLOSOBRE LAS FUERZAS DE REACCIÓN DEL SUELO DURANTELOS SALTOS EN SIMULACIÓN DE JUEGO DE BALONCESTO
\end{abstract}

\section{Alex Castro 1,2 (D) \\ (Physical Education Professional) \\ Márcio Fagundes Goethel ${ }^{2}$ (ID \\ (Physical Education Professional) \\ Edgar Ramos Vieira ${ }^{3}$ (ID) \\ (Physiotherapist) \\ Pedro Vieira Sarmet Moreira ${ }^{2}$ (ID (Physical Education Professional) \\ Antônio Francisco de Almeida \\ Neto ${ }^{2}$ (ID \\ (Physiotherapist) \\ Adalgiso Coscrato Cardozo ${ }^{2}$ (ID \\ (Physical Education Professional) \\ Denis Brunt ${ }^{3}$ (ID \\ (Physiotherapist) \\ Mauro Gonçalves ${ }^{2}$ \\ (Physical Education Professional)}

1. Universidade de Campinas, Faculty of Physical Education, Laboratory of Exercise Physiology, Campinas, SP, Brazil.

2. São Paulo State University,

Department of Physical Education, Laboratory of Biomechanics, Rio Claro, SP, Brazil.

3. Florida International University, Department of Physical Therapy, Miami, Florida, USA.

\section{Correspondence:}

Alex Castro. Laboratory of Exercise Physiology, Faculty of Physical Education, University of Campinas. Avenida Érico Veríssimo, 701, Cidade Universitária Zeferino Vaz, Barão Geraldo, Campinas, SP, Brazil. 13083-851

ax.castro@yahoo.com.br

\section{ABSTRACT}

Introduction: The use of ankle braces reduces the risk of ankle injuries in basketball players. However, the mechanisms of injury protection provided by the ankle braces in the basketball game are still unknown. Objectives: To analyze the effects of wearing a lace-up ankle brace, and to conduct an exercise protocol that simulated the intensity of the basketball game on ground reaction force (GRF) during basketball-specific vertical jumps. Methods: Eleven male younger basketball players aged under 18 completed 48 vertical jumps, with and without ankle braces, during an exercise protocol composed of four 10-minute periods, simulating the activity profile and intensity of the basketball game as well as the typical intervals between periods. Mediolateral (variables: the greatest medial and lateral peaks) and vertical (variables: vertical peak, impulse peak, impulse at 50 ms of landing, loading rate and jump height) GRF were measured during takeoff and landing for all the jumps performed in the exercise protocol. Results: The use of the ankle brace reduced mediolateral GRF in all periods of the exercise protocol during takeoff and landing $(P<0.05)$, without affecting the vertical GRF ( $P>0.05)$. Mediolateral and vertical GRF (takeoff mediolateral vertical peaks, landing mediolateral peaks, landing impulse peak, takeoff and landing loading rate) increased significantly during four subsequent 10-minute periods $(P<0.05)$. However, for mediolateral GRF, the increase overtime was higher without braces. Conclusions: The use of the ankle brace reduced the mediolateral GRF on the lower limb, while there was a progressive increase in the external load applied to the body during the vertical jumps in the subsequent periods of the exercise protocol performed at the same intensity of the basketball game. Level of evidence l; Randomized clinical trial.

Keywords: Sprains and strains; Wounds and injuries; Basketball.

\section{RESUMO}

Introdução: O uso de órtese de tornozelo reduz o risco de lesões no tornozelo em jogadores de basquetebol. No entanto, os mecanismos de proteção de lesão fornecidos pelas órteses durante o jogo de basquetebol ainda são desconhecidos. Objetivos: Analisar o efeito do uso de órtese de tornozelo lace-up (com cordão) e de um protocolo de exercício que simulou a intensidade do jogo de basquetebol sobre a força de reação do solo (FRS) durante saltos verticais específicos do basquetebol. Métodos: Onzejogadores de basquetebol do sexo masculino com menos de 18 anos realizaram 48 saltos verticais, come sem órtese de tornozelo, durante um protocolo de exercícios composto por quatro períodos de 10 minutos, que simularam o perfil de atividade e intensidade do jogo de basquetebol, assim como os intervalos típicos entre os períodos. As FRSs mediolaterais (variáveis: maiores picos medial lateral) everticais (variáveis: pico vertical, pico de impulso, impulso em 50 ms da aterrissagem, taxa de sobrecarga e altura do salto) foram medidas durante as fases de decolagem e aterrissagem de todos os saltos realizados no protocolo de exercício. Resultados: O uso de órtese reduziu a FRS mediolateral em todos os períodos analisados, durante as fases de decolagem e aterrissagem $(P<0,05)$, sem afetar a FRS vertical $(P>0,05)$. AFRS mediolateral evertical (picos mediolateral evertical de decolagem, picos mediolaterais de aterrissagem, pico de impulso de aterrissagem, taxa de sobrecarga na decolagem e aterrissagem) aumentaram significativamente durante quatro períodos subsequentes de 10 minutos $(P<0,05)$. No entanto, para a FRS mediolateral, o aumento ao longo do tempo foi maior sem o uso de órtese. Conclusões: O uso de órtese de tornozelo reduziu a FRS mediolateral no membro inferior, enquanto houve um aumento progressivo da carga externa aplicada ao corpo durante os saltos nos períodos subsequentes do protocolo de exercícios com mesma intensidade do jogo de basquetebol. Nível de evidencia l; Estudo clínico randomizado.

Descritores: Entorses e distensões; Ferimentos e lesões; Basquetebol.

\section{RESUMEN}

Introducción: El uso de órtesis de tobillo reduce el riesgo de lesiones en el tobillo en jugadores de baloncesto. Sin embargo, los mecanismos de protección de lesión proporcionados por las órtesis durante el juego de baloncesto aún son desconocidos. Objetivos: Analizar el efecto del uso deórtesis de tobillo lace-up (con cordón) y de un protocolo de ejercicio que 
simuló la intensidad del juego de baloncesto sobre la fuerza de reacción del suelo (FRS) durante saltos verticales especificos del baloncesto. Métodos: Once jugadores de baloncesto del sexo masculino con menos de 18 años realizaron 48 saltos verticales, con y sin órtesis de tobillo, durante un protocolo de ejercicios compuesto por cuatro períodos de 10 minutos, que simularon el perfil de actividad e intensidad del juego de baloncesto, así como los intervalos típicos entre los períodos. Las FRS mediolaterales (variables: mayores picos medialy lateral) yverticales (variables: pico vertical, pico de impulso, impulso en $50 \mathrm{~ms}$ de aterrizaje, tas a de sobrecarga y altura del salto) fueron medidas durante las fases de despeguey aterrizaje de todos saltos realizados en el protocolo de ejercicio. Resultados: El uso de órtesis redujo la FRS mediolateral en todos los períodos analizados, durante las fases de despegue y aterrizaje $(P<0,05)$, sin afectar la FRS vertical $(P>0,05)$. La FRS mediolateral y vertical (picos mediolateral y vertical de despegue, picos mediolaterales de aterrizaje, pico de impulso de aterrizaje, tasa de sobrecarga en el despegue y aterrizaje) aumentaron significativamente durante cuatro períodos subsiguientes de 10 minutos $(P<0,05)$. Sin embargo, para la FRS mediolateral, el aumento a lo largo del tiempo fue mayor sin el uso de órtesis. Conclusiones: El uso de órtesis de tobillo redujo la FRS mediolateral en el miembro inferior, mientras que hubo un aumento progresivo de la carga externa aplicada al cuerpo durante los saltos en los períodos subsiguientes del protocolo de ejercicios con la misma intensidad del juego de baloncesto. Nivel de evidencia l; Ensayo clínico aleatorizado.

Descriptores: Esguinces y distensiones; Heridas y traumatismos; Baloncesto.

\section{INTRODUCTION}

Ankle injuries are the most common in basketball, accounting for $16-24 \%$ of all injuries. ${ }^{1,2}$ Currently, one of the methods commonly used to prevent the occurrence of ankle injuries in the basketball is the use of lace-up ankle braces. ${ }^{3}$

Wearing braces can increase ankle stability and reduce the risk of injury, by decreasing the velocity and range of motion of the ankle during jumps. ${ }^{4-6}$ However, results in literature on other biomechanics variables involved in the jump, such as the ground reaction force (GRF) are contrasting. ${ }^{4-11}$ For instance, Sacco et al. ${ }^{9}$ and Castro et al. ${ }^{8}$ demonstrated decreased mediolateral GRF during jump takeoff and landing, respectively, in basketball players wearing ankle brace, without changes in vertical GRF. Riemann et al., ${ }^{12}$ Cordova et al. ${ }^{11}$ and Simpson et al. ${ }^{10}$ showed increased loading rate of vertical GRF and reduced time to peak vertical GRF, while DiStefano et al. ${ }^{4}$ did not observed any changes in the vertical GRF, during drop landing task wearing ankle brace. More recently, Dewar et al. ${ }^{5,6}$ demonstrated reduced ankle and foot inversion, and increased ankle inversion moments during basketball rebounding task.

Most of these studies have evaluated only the immediate effects of wearing an ankle brace on biomechanics variables of the jump, 4-6,9-11 which implies in limited inference about the mechanisms of injury protection provide by use of ankle brace during the actual basketball games.

In this sense, it has been found that usefulness of ankle bracing is limited if the aim is to restrict range of motion and improve proprioceptive capability under intermittent exercises soccer-specific. ${ }^{13}$ or to prevent the strength decline of ankle's stabilizing muscles over an exercise at the same intensity of basketball game. ${ }^{14}$ To our knowledge, no previous study has investigated the effects of ankle bracing on external forces applied to human body during a basketball game. Then, it is possible to question whether the use of ankle brace is effective to reduce the magnitude of external forces applied to the body for all time, despite the accumulated fatigue by the basketball game.

To investigate the mechanical loads during vertical jumps in situations representative of basketball game conditions is important for understanding of vertical jump-related ankle injuries in basketball players ${ }^{8,9}$ and provide a more practical assessment of the effects of the use ankle bracing in basketball game. The aim of this study was to analyze the effects of wearing an ankle brace on GRF during vertical jumps during an exercise protocol that simulated the intensity and induced-fatigue by a basketball game. The main hypothesis tested was that with the basketball game simulation the external forces applied to the body during vertical jumps would increase and that brace would reduce the GRF magnitude, but these effects would decrease significantly due to the prolonged exercise.

\section{METHODS \\ Participants}

The participants of this study were the same from our previous publication (11 amateur young male basketball players under-18, idade: 17,1 \pm 0,1 anos; massa corporal: 75,6 \pm 9,0 kg; estatura: 183,3 $\pm 8,7 \mathrm{~cm}$ ), including three guards, three centers and five forwards. The sample characteristics have been described in details previously. ${ }^{8}$ Briefly, all participants were free from: ankle and foot injuries in the last 12 months; mechanical ankle instability; and functional ankle instability. ${ }^{8}$ All participants read and signed an informed consent form approved by the institutional review board (\# 014/2011) and conducted in conformity with the Declaration of Helsinki, revised in 2008. The sample size was calculated using G*Power 3.2.1 software (Franz Faul, Universitat Kiel, Germany), assuming a type I error rate (a) of 5\%, moderate expected effect size (Cohen's $f=0.3$ ) for the condition*period interaction, correlation between repeated measures $(r)$ of 0.75 and correction of non-sphericity $(\varepsilon)$ as 1 , to promote a statistical power of at least $80 \%$.

\section{Procedures}

In the day before main testing, the participants performed five minutes of warm-up on a cycle ergometer (Cefise ${ }^{\circledR}$, Nova Odessa, BRA). Then, they completed 3 maximal vertical jumps with $30 \mathrm{~s}$ of recovery to determine the target maximum vertical range achieved by the athlete for testing ${ }^{8}$. After, participants were familiarized with the protocol of exercises.

On the day of testing, participants warmed up by cycling on the ergometric bicycle (Cefise ${ }^{\star}$, Nova Odessa, BRA) for five minutes. Then, they completed vertical jumps with and without wearing ankle braces bilaterally, during a 40 min (four ten-minute periods) of basketbalI-specific fatigue protocol performed on ground and treadmill at varying intensities simulating the characteristics of a basketball game as previously demonstrated. ${ }^{14,15}$ The ankle brace tested was a lace-up type (Horse Jump ${ }^{\circ}$, Franca, Brazil) (Figure 1) and selected due to its perceived comfort, ease of application, ${ }^{16}$ reducing the incidence of ankle injuries and popularity among basketball players. ${ }^{3}$ The braces were positioned on the participants' ankles by the same evaluator in all tests and refitted prior to the beginning of each protocol period to avoid excessive laxity. Ankle braces were used continuously throughout the exercise protocol (40 min) and vertical jumps. The order of the testing conditions (with and without ankle braces) was randomized through computer-generated random binary numbers. Thus, five participants started the first trial with brace while six without 
brace. An interval of at least $48 \mathrm{~h}$ was performed between the test sessions. In every test condition, trials were performed at the same day period and similar environmental conditions (temperature: without brace $=22.6 \pm 1.0^{\circ} \mathrm{C}$; with brace $=22.4 \pm 0.7^{\circ} \mathrm{C}$ ). All athletes were instructed to not perform a heavy training session in the day before the testing session.

Each testing session was divided into four identical ten-minute periods of the intermittent exercises ${ }^{14,15}$ simulating the typical demands of a basketball game ${ }^{17}$ including: running velocities (1-6 m.s . $\left.^{-1}\right)_{1}^{18}$ time spent to change the movement pattern $(\approx 3 \mathrm{~s})$, total distances covered $(\approx 6000 \mathrm{~m}){ }_{1}^{17}$ distances covered in moderate to high intensity ( $\approx 56 \%$ occur in 1-5 m) ${ }^{19}$ time spend with ball possession (72\% last 1-40 s) ${ }^{19}$ breaks in activity (80\% last 1-40 s), ${ }^{19}$ number of jumps (about 12 per period), changes in direction/cutting maneuvers (mean cutting angle is about $\left.45^{\circ}\right)$, heart rate (151-171 beats. $\left.\mathrm{min}^{-1}\right)^{17}$ and perceived exertion (12-14 on Borg scale) ${ }^{18}$ comparable to basketball game conditions. The protocol of exercises was described in details in the Figure 2.

Vertical jumps simulating rebounds were performed on a force plate (AMTI', Watertown, EUA) operating at $2000 \mathrm{~Hz}$, with 4000 times gain and a 12-bit A/D converter. The participants started the jump from standing
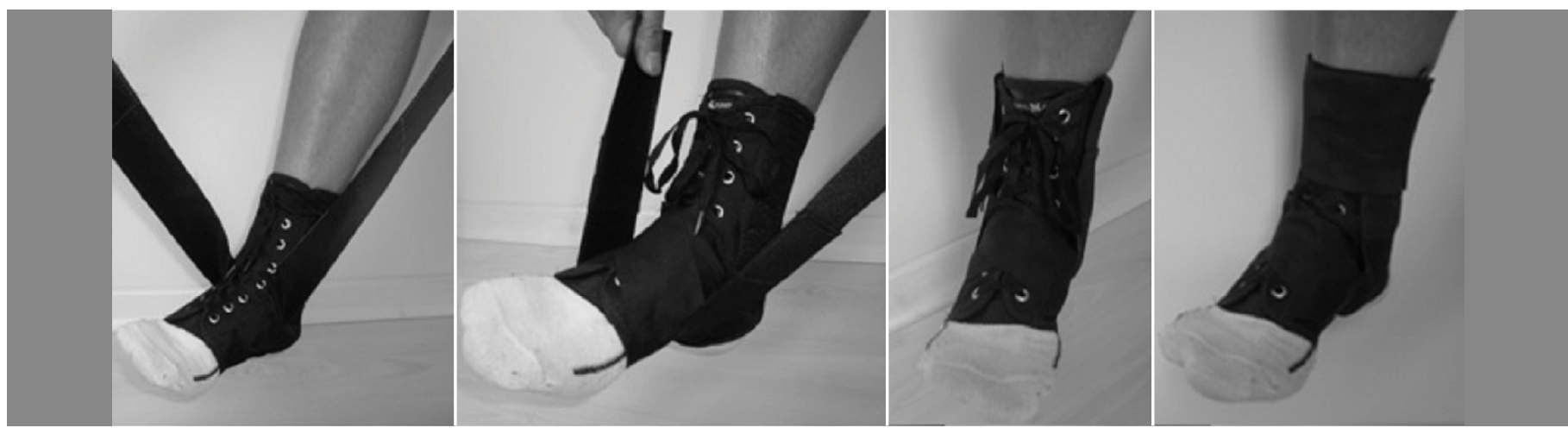

Figure 1. Lace-up ankle brace.

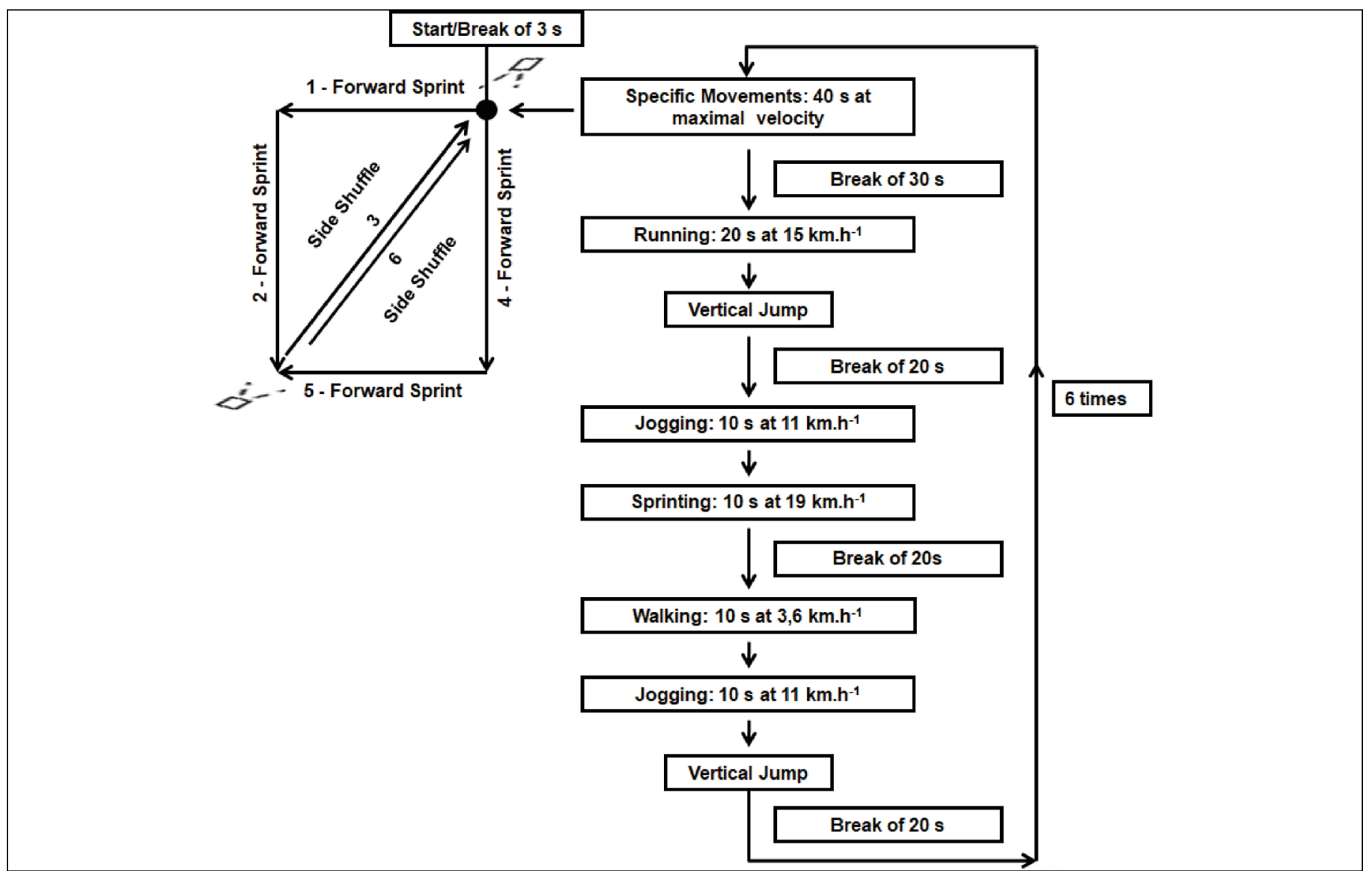

Figure 2. Sequence of activities during the simulated basketball game. Reproduced according previous studies.14,15 The test began in a rectangle (width: 3 m; length: $4 \mathrm{~m}$ ) marked on the ground, where the participants performed running, changes in direction and side shuffle. An auditory clue was given by a photocells system (Cefise ${ }^{\circledast}$ Nova Odessa, BRA) to initiate the test. Then, the participant run the following sequence as fast as possible: forward sprint ( 3 m), change in direction ( $\left.90^{\circ}\right)$, forward sprint $(4 \mathrm{~m})$ and side shuffle $\left(5 \mathrm{~m}\right.$ at $\left.45^{\circ}\right)$. After a three-second break this sequence was repeated in a different direction randomly determined, continuously by $40 \mathrm{~s}$, and followed by $30 \mathrm{~s}$ interval. After that, the participants ran on the treadmill (Inbramed ${ }^{\oplus}$, Gravataí, BRA), with inclination kept fixed at 1\%, in varying speeds and distances typical of a basketball game 18 and then completed vertical jumps simulating rebounds on the force plate. The following sequence was completed: running at $15 \mathrm{~km} . \mathrm{h}^{-1}$ for $20 \mathrm{~s}$, vertical jump, $20 \mathrm{~s}$ break, jogging at $11 \mathrm{~km} \cdot \mathrm{h}^{-1}$ for $10 \mathrm{~s}$, sprinting at $19 \mathrm{~km} \cdot \mathrm{h}^{-1}$ for $10 \mathrm{~s}, 20 \mathrm{~s}$ break, walking at $3.6 \mathrm{~km} . \mathrm{h}^{-1}$ for $10 \mathrm{~s}$, jogging at $11 \mathrm{~km}$. h-1 for $10 \mathrm{~s}$, vertical jump, and 20 $s$ break. Participants were given verbal encouragement throughout the test. These tasks were repeated 6 times, totaling ten-minute of exercise, simulating a quarter (one period) of the basketball game. To simulate the real basketball game were performed four ten-minute periods ( $40 \mathrm{~min}$ ). There was a two-minute break between the first and second periods, a fifteen-minute break between the second and third periods, and a two minute break between the third and fourth periods ${ }^{20}$. 
position with the arms alongside the body and were instructed to jump straight up and touch with both hands a basketball hanging at $95 \%$ of the participant's maximum vertical range previously measured. Arm swing was allowed and knee angle during the jump takeoff phase was not controlled to ensure a more realistic simulation of the rebound jump in basketball. The ball was positioned $5 \mathrm{~cm}$ anteriorly to the center of the force plate so that the participants could see the ball in them front during takeoff. Each participant wore their own basketball shoes and the same pair was used for both conditions (with and without ankle brace).

\section{Measures of exercise intensity}

Exercise intensity was measured based on the heart rate monitoring (Polar Kempele, FIN) and perceived exertion at the completion of each treadmill running speed and ground activity (actions at rectangle area and jumps). The heart rate and perceived exertion ${ }^{21}$ ( $6=$ minimum; 20 $=$ maximum) were recorded at the end and the last $5 \mathrm{~s}$, respectively, of each action performed on treadmill and ground (retangle area). Mean heart rate and perceived exertion were calculated for each ten-minute period during each testing condition.

\section{Data Analysis}

The GRF were normalized by body weight (BW) and the final values were considered as the arithmetic average of the twelve vertical jumps for each ten-minute period and tested condition. The data was filtered using a low pass Butterworth digital filter of $4^{\text {th }}$ order at $95 \mathrm{~Hz}$ based on residual analysis. ${ }^{22}$ Prior to each testing session, the force plate was calibrated in accordance with manufacturer guidelines
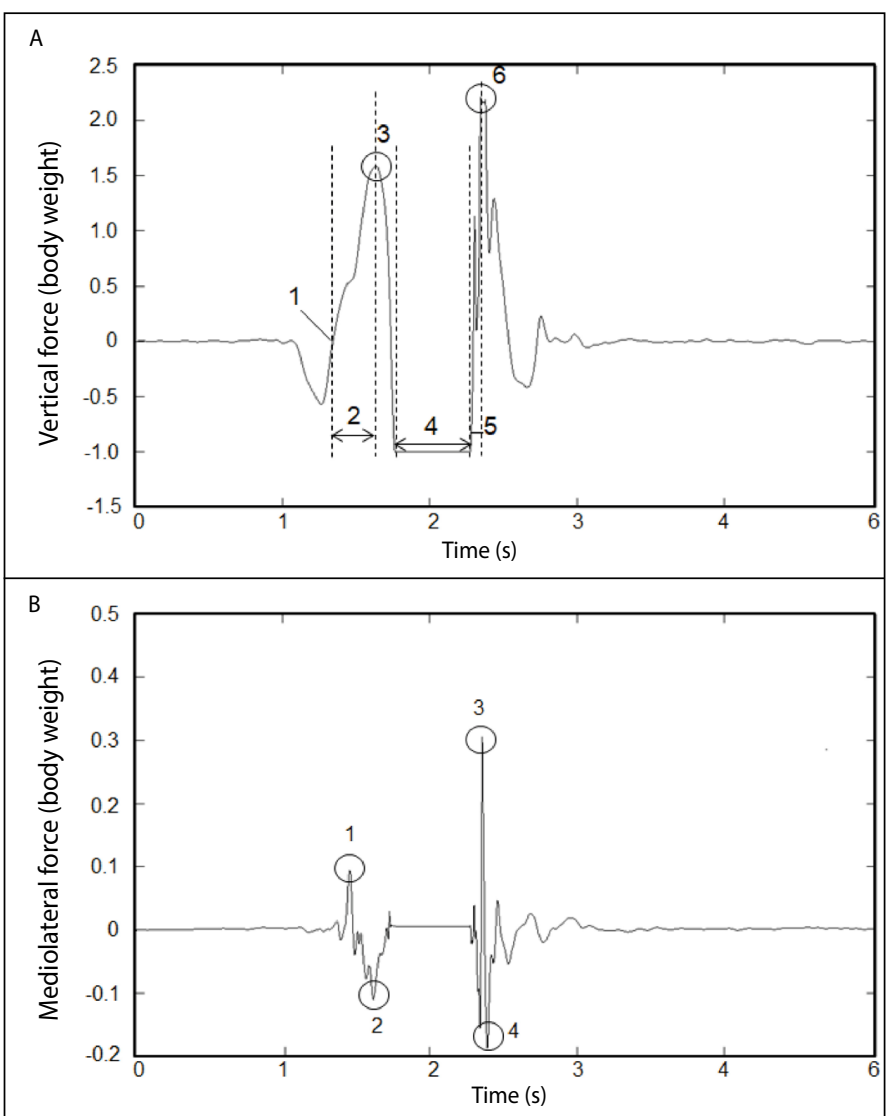

Figure 3. Graphical representation of vertical and mediolateral ground reaction forces during vertical jump in the basketball game simulation. A: Vertical ground reaction force. 1 = onset of takeoff; 2 = takeoff loading rate; 3 = takeoff vertical peak; 4 = air time; 5 = landing loading rate; $6=$ landing vertical peak. B: Resultant mediolateral ground reaction force. 1 = takeoff medial peak (body right side); 2 = takeoff lateral peak (body left side); 3 = landing medial peak; 4 = landing lateral peak.
For the vertical GRF data were analyzed: (Figure 3A) takeoff vertical peak (ICC $=0.91)$, landing vertical peak $($ ICC $=0.99)$, takeoff impulse peak (ICC $=0.97)$, landing impulse peak (ICC $=0.81)$, impulse at 50 ms of landing $(\text { ICC }=0.81)^{8}$, jump height based on flight time method $(I C C=0.99)^{23}$, takeoff loading rate (ICC $=0.90)$ and landing loading rate $(I C C=0.99)^{24}$.

For the resultant mediolateral GRF data, were analyzed: (Supplementary Figure 3B) the greatest takeoff and landing medial peaks (ICC $=0.92$ and ICC $=0.98$, respectively), and the greatest takeoff and landing lateral peaks (ICC $=0.98$ and ICC $=0.95$, respectively) ${ }^{8,9}$ Considering that the anteroposterior GRF has not been associated to the risk of ankle injury during vertical jumps, ${ }^{4-6,9,11}$ these data were not presented.

\section{Statistical Analysis}

Normality of distribution was checked using the Shapiro-Wilk test. The differences between and within-condition for each dependent variable (GRF variables) were tested using two-way repeated-measures analysis of variance (ANOVA), assuming as independent variables condition (with and without brace) and period (periods 1, 2, 3 and 4). Assumptions of sphericity were evaluated using Mauchly's test. Where sphericity was violated $(P<0.05)$, the Greenhouse-Geisser correction factor was applied. Whenever a significant ANOVA main effect (period and condition) or interaction (period ${ }^{*}$ condition) were obtained, post hoc analysis were made using the Bonferroni test. All tests were performed using the software PASW statistics 18.0 (SPSS Inc., Chicago, USA). The significance level was set at $P \leq 0.05$. The reliability of data was examined by the ICC (test-retest for period $1 ; n=5)$, using the spreadsheet of Hopkins. ${ }^{25}$

\section{RESULTS}

For the mediolateral GRF, repeated measures ANOVA showed a significant period ${ }^{*}$ condition interaction for landing medial peak $(P<$ 0.001 ) and takeoff lateral peak $(P<0.001)$, as well as significant main effects of period and condition for takeoff medial peak $(P<0.001$ and $P$ $<0.001$, respectively) and landing lateral peak $(P=0.001$ and $P=0.001$, respectively). The medial peaks were significantly smaller with braces than without braces for all periods during takeoff $(P<0.001$, mean difference $=-16 \%)$, and for periods $2(P=0.04,-11 \%), 3(P=0.015,-13 \%)$ and $4(P=0.018,-17 \%)$ during landing. Similarly, the lateral peaks were significantly smaller with braces than without braces for periods $2(P=$ $0.002,-11 \%), 3(P=0.003,-14 \%)$ and $4(P=0.004,-17 \%)$ during takeoff, and for all periods during landing $(P<0.001$, mean difference $=-9 \%)$. Additionally, for both with and without braces condition, takeoff medial and landing lateral peaks increased after the period 3 , when comparing periods 1 and 3 (takeoff medial peak: $P=0.015,+20 \%$; landing lateral peak: $P=0.016,+12 \%), 1$ and 4 (takeoff medial peak: $P<0.001,+27 \%$; landing lateral peak: $\mathrm{P}=0.009,+17 \%), 2$ and 3 (landing lateral peak: $\mathrm{P}=$ $0.005,+5 \%), 2$ and 4 (takeoff medial peak: $P=0.044,+18 \%$; landing lateral peak: $P=0.002,+10 \%), 3$ and 4 (landing lateral peak: $P=0.003,+5 \%)$. On the other hand, takeoff lateral and landing medial peaks increased after the period 2 without braces, but only after the period 3 with braces. Takeoff lateral peak increased when comparing periods 1 and 2 (without brace: $P=0.001,+11 \%), 1$ and 3 (without brace: $P<0.001,+21 \%$; with brace: $P=0.022,+7 \%), 1$ and 4 (without brace: $P<0.001,+35 \%$; with brace: $P<0.001,+16 \%), 2$ and 3 (without brace: $P=0.003,+9 \%), 2$ and 4 (without brace: $P<0.001,+21 \%$; with brace: $P=0.001,+14 \%), 3$ and 4 (without brace: $P=0.008,+12 \%$; with brace: $P=0.006,+8 \%$ ). Landing medial peak increased when comparing periods 1 and 2 (without brace: $P=0.026,+10 \%), 1$ and 3 (without brace: $P=0.009,+18 \%$; with brace: $P=0.002,+12 \%), 1$ and 4 (without brace: $P=0.002,+29 \%$; with brace: $P=0.01,+17 \%) ; 2$ and 3 (without brace: $P=0.027,+8 \%$; with brace: $P$ $=0.003,+5 \%), 2$ and 4 (without brace: $P=0.001,+17 \%$; with brace: $P=$ $0.014,+10 \%), 3$ and 4 (without brace: $P=0.02,+9 \%$ ). (Table 1) 
For the vertical GRF variables, there were no significant perio$d^{*}$ condition interaction or main effects of condition $(P>0.05$ for all variables). However, repeated measures ANOVA showed significant main effects of period for takeoff vertical peak $(P=0.002)$, landing impulse peak $(P=0.001)$, impulse at $50 \mathrm{~ms}$ of landing $(P=0.022)$, takeoff loading rate $(P<0.001)$ and landing loading rate $(P<0.001)$. In both conditions, there were significant increases overtime during subsequent periods of the simulated basketball game for: takeoff vertical peak from period 1 to periods 3 $(P=0.019,+4 \%)$ and $4(P=0.019,+7 \%)$; landing impulse peak from period 1 to period $4(\mathrm{P}=0.016,+20 \%)$; takeoff loading rate from period 1 to periods $2(P=0.004,+10 \%), 3(P=0.001,+15 \%)$ and 4 $(P=0.005,+18 \%)$; landing loading rate from period 1 to periods 2 $(P=0.025,+8 \%), 3(P=0.001,+15 \%)$ and $4(P=0.003,+24 \%)$, period 2 to periods $3(P=0.012,+7 \%)$ and $4(P=0.007,+15 \%)$, period 3 to $4(P=0.05,+8 \%)$. For impulse at $50 \mathrm{~ms}$ of landing, only a trend towards significance was observed from period 1 to period 4 $(P=0.076)$ and period 2 to period $4(P=0.058)$. There were no significant differences for landing vertical peak, takeoff impulse peak and jump height between conditions or periods tested ( $P>0.05$ for all). (Table 2)

There were no significant period ${ }^{*}$ condition interactions for heart rate or perceived exertion scores ( $P>0.05$ for all). On the other hand, repeated measures ANOVA showed a significant main effect of period for perceived exertion ( $P=0.009)$, demonstrating increases in both conditions from period 1 to periods 2 ( $P=0.018,+1$ point), 3 ( $P=0.009$, +2 points) and $4(P=0.01,+2$ points). (Table 3$)$

\section{DISCUSSION}

Wearing the ankle brace during four periods of an exercise protocol at the similar intensity of basketball game resulted in lower increase in the mediolateral GRF during vertical jumps, without changing vertical GRF. Moreover, our protocol designed to induce fatigue similar to that experienced in a basketball match promoted the increase in the vertical and mediolateral GRF applied to the lower limb during takeoff and landing jump.

The lack of significant differences between the vertical GRF with and without ankle brace during vertical jumps corroborates with previous studies $^{4,8,9}$ and can be attributed to the increased knee flexion typically observed during landing jump when wearing an ankle brace, which compensated for the decreased sagittal ankle movements. ${ }^{4}$

The ankle brace reduced the resultant mediolateral forces during takeoff and landing after the first period of exercise protocol, reflecting an increased ankle mediolateral stability. Supporting our findings, Sacco et al. ${ }^{9}$ and Castro et al. ${ }^{8}$ demonstrated decreased mediolateral

Table 3. Heart rate and perceived exertion during the four 10-minute periods, with and without brace $(n=11)$.

\begin{tabular}{c|c|c|c|c|c|c|c|c}
\hline \multirow{2}{*}{ Variables } & \multicolumn{3}{|c|}{ Without Ankle Brace } & \multicolumn{4}{c}{ With Ankle Brace } \\
\cline { 2 - 9 } & P1 & P2 & P3 & P4 & P1 & P2 & P3 & P4 \\
\hline Heart rate & 163 & 163 & 161 & 162 & 161 & 164 & 160 & 162 \\
(beats.min $\left.^{-1}\right)$ & $(12)$ & $(9)$ & $(12)$ & $(13)$ & $(8)$ & $(9)$ & $(10)$ & $(11)$ \\
\hline Perceived exertion & 11 & 12 & 13 & 13 & 11 & 12 & 13 & 13 \\
(Borg scale) $^{\text {a }}$ & $(2)$ & $(2)^{*}$ & $(1)^{*}$ & $(1)^{*}$ & $(2)$ & $(2)^{*}$ & $(2)^{*}$ & $(1)^{*}$ \\
\hline
\end{tabular}

Note: Periods 1 (P1), 2 (P2), 3 (P3) and 4 (P4). a: Significant ANOVA main effect of period $(\mathrm{P}<0.05)$. *: Significant difference from $P 1(P<0.05)$ in post hoc analysis. Data are mean ( \pm standard deviation).

Table 1. Parameters of mediolateral GRF during the four ten-minute periods, with and without brace $(n=11)$.

\begin{tabular}{|c|c|c|c|c|c|c|c|c|}
\hline \multirow{2}{*}{ Variables } & \multicolumn{4}{|c|}{ Without Ankle Brace } & \multicolumn{4}{|c|}{ With Ankle Brace } \\
\hline & P1 & P2 & P3 & P4 & P1 & P2 & P3 & P4 \\
\hline \multirow{2}{*}{$\begin{array}{c}\text { Takeoff Medial } \\
\text { peak }(B W)^{a b}\end{array}$} & 0.0318 & 0.0345 & $0.0391^{*}$ & $0.0427^{* \dagger}$ & $0.0282^{\S}$ & $0.0300^{5}$ & $0.0327^{* \S}$ & $0.0336^{*+5}$ \\
\hline & 0.0087 & 0.0104 & 0.0094 & 0.0090 & 0.0075 & 0.0089 & 0.0119 & 0.0050 \\
\hline \multirow{2}{*}{$\begin{array}{l}\text { Landing Medial } \\
\text { peak }(B W) c\end{array}$} & 0.1428 & $0.1572^{*}$ & $0.1692^{* \dagger}$ & $0.1837^{* 1 \neq}$ & 0.1314 & $0.1394^{5}$ & $0.1466^{*+5}$ & $0.1534^{*+5}$ \\
\hline & 0.0581 & 0.0690 & 0.0724 & 0.0792 & 0.0520 & 0.0568 & 0.0581 & 0.0635 \\
\hline \multirow{2}{*}{ Takeoff Lateral peak (BW)c } & -0.0448 & $-0.0497^{*}$ & $-0.054^{*+}$ & $-0.0603^{*+\neq}$ & -0.0433 & $-0.0441^{\S}$ & $-0.0465^{* \S}$ & $-0.0503^{*+\neq 5}$ \\
\hline & 0.0074 & 0.0067 & 0.0073 & 0.0093 & 0.0064 & 0.0065 & 0.0050 & 0.0068 \\
\hline \multirow{2}{*}{$\begin{array}{l}\text { Landing Lateral } \\
\text { peak (BW) }\end{array}$} & -0.1612 & -0.1726 & $-0.1808^{*+}$ & $-0.1914^{*+\neq}$ & $-0.1481^{\S}$ & $-0.1589^{5}$ & $-0.1664^{*+5}$ & $-0.1718^{* \neq \neq 5}$ \\
\hline & 0.0371 & 0.0435 & 0.0429 & 0.0465 & 0.0302 & 0.0350 & 0.0412 & 0.0464 \\
\hline
\end{tabular}

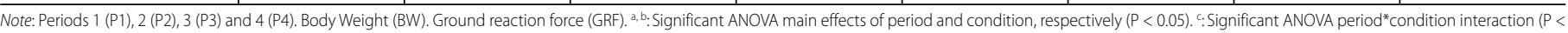
$0.05) . *{ }^{*},+$ : : Significant difference from $\mathrm{P} 1, \mathrm{P} 2$ and $\mathrm{P} 3$ in post hoc analysis, respectively $(\mathrm{P}<0.05)$. ${ }^{\mathrm{s}}$ : Significant difference from without brace condition in post hoc analysis $(\mathrm{P}<0.05)$.

Table 2. Dynamical parameters of vertical GRF during the four ten-minute periods, with and without brace $(n=11)$.

\begin{tabular}{|c|c|c|c|c|c|c|c|c|}
\hline \multirow{2}{*}{ Variables } & \multicolumn{4}{|c|}{ Without Ankle Brace } & \multicolumn{4}{|c|}{ With Ankle Brace } \\
\hline & P1 & P2 & P3 & P4 & P1 & P2 & P3 & P4 \\
\hline \multirow{2}{*}{$\begin{array}{c}\text { Takeoff vertical } \\
\text { peak }(\mathrm{BW})^{\mathrm{a}}\end{array}$} & 1.9485 & 1.9980 & 2.0237 & 2.0759 & 1.9574 & 2.0222 & 2.0247 & 2.0972 \\
\hline & $(0.2725)$ & $(0.2509)$ & $(0.2357)^{*}$ & $(0.2699)^{*}$ & $(0.2466)$ & $(0.2862)$ & $(0.2736)^{*}$ & $(0.2916)^{*}$ \\
\hline \multirow{2}{*}{$\begin{array}{c}\text { Landing vertical } \\
\text { peak (BW) }\end{array}$} & 2.6764 & 2.7107 & 2.7420 & 2.7715 & 2.6971 & 2.7325 & 2.7598 & 2.8570 \\
\hline & $(0.6151)$ & $(0.6113)$ & $(0.6031)$ & $(0.6044)$ & $(0.6019)$ & $(0.5965)$ & $(0.5974)$ & $(0.6486)$ \\
\hline \multirow{2}{*}{$\begin{array}{c}\text { Takeoff impulse } \\
\text { peak (BW.s) }\end{array}$} & 0.2500 & 0.2503 & 0.2498 & 0.2539 & 0.2482 & 0.2470 & 0.2517 & 0.2469 \\
\hline & $(0.0492)$ & $(0.0507)$ & $(0.0468)$ & $(0.0466)$ & $(0.0564)$ & $(0.055)$ & $(0.0672)$ & $(0.0589)$ \\
\hline \multirow{2}{*}{$\begin{array}{c}\text { Landing impulse } \\
\text { peak (BW.s) }\end{array}$} & 0.0778 & 0.0872 & 0.0907 & 0.0996 & 0.0807 & 0.0870 & 0.0917 & 0.0899 \\
\hline & $(0.0233)$ & $(0.0278)$ & $(0.0309)$ & $(0.0336)^{*}$ & $(0.0181)$ & $(0.0202)$ & $(0.0233)$ & $(0.0206)^{*}$ \\
\hline \multirow{2}{*}{$\begin{array}{c}\text { Impulse at } 50 \text { ms of } \\
\text { landing }(B W . s)^{a}\end{array}$} & 0.0600 & 0.0618 & 0.0615 & 0.0658 & 0.0617 & 0.0628 & 0.0638 & 0.0642 \\
\hline & $(0.0160)$ & $(0.0154)$ & $(0.0150)$ & $(0.0157)$ & $(0.0140)$ & $(0.0135)$ & $(0.0133)$ & $(0.0120)$ \\
\hline \multirow{2}{*}{$\begin{array}{c}\text { Takeoff loading } \\
\text { rate (BW.s-1)a }\end{array}$} & 13.237 & $14.182^{*}$ & $14.556^{*}$ & $15.204^{*}$ & 14.059 & $15.786^{*}$ & $16.771^{*}$ & $16.892^{*}$ \\
\hline & $(2.860)$ & (3.079) & $(4.137)$ & $(4.871)$ & $(2.328)$ & (3.283) & (3.653) & (3.839) \\
\hline \multirow{2}{*}{$\begin{array}{l}\text { Landing loading } \\
\text { rate }(B W . s-1)^{\mathrm{a}}\end{array}$} & 194.170 & $206.599 *$ & $228.621^{*}+$ & $239.339 *$ † & 200.478 & $220.242^{*}$ & $226.875^{*}+$ & $250.376^{*}+\neq$ \\
\hline & $(55.914)$ & $(65.554)$ & $(66.379)$ & $(68.310)$ & $(66.783)$ & $(73.642)$ & $(73.025)$ & $(87.599)$ \\
\hline \multirow{2}{*}{ Jump height (m) } & 0.4643 & 0.4599 & 0.4610 & 0.4645 & 0.4553 & 0.4537 & 0.4570 & 0.4630 \\
\hline & $(0.0790)$ & $(0.0789)$ & $(0.0771)$ & $(0.0752)$ & $(0.0822)$ & $(0.0814)$ & $(0.0781)$ & $(0.0822)$ \\
\hline
\end{tabular}


GRF during jump takeoff and landing performed by basketball players wearing ankle braces. Other studies also attribute the increased mediolateral stability to the stiffness offered by the ankle brace, which reduces ankle inversion/eversion velocity and range of motion, attenuating the external forces that cause ankle motion. ${ }^{5,6,26-28}$ In our study, the additional mediolateral stability provided by the ankle brace was particularly important on later periods (i.e. $4^{\text {th }}$ period), protecting against increased risk of ankle injuries due to fatigue. ${ }^{29}$

These findings have implications for prevention of ankle injuries that occurs due to landing on court surface (without contact between players), which represent half of all ankle injuries recorded during jump landing in basketball game. ${ }^{30}$ One of the mechanisms associated to these injuries is the inability of the athlete to effectively control excessive displacement of the center of gravity beyond the lateral border of the weightbearing foot, increasing lateral postural sway and risk of ankle injury, mainly of the ankle's lateral ligaments. ${ }^{31}$ Thus, assuming that a body is in equilibrium when the sum of all forces and moments of force acting on it is zero, ${ }^{32}$ the reduced magnitude of mediolateral GRF observed with brace in the present study suggests a body more stable during landing jump and less susceptible to injury in basketball game.

We also demonstrated that the loading experienced by the athlete's body structure and the rate at which peak force is produced progressively increased, as evidenced by the maintenance of the physical demands between periods, while perceived exertion, impulse peak, loading rate and mediolateral peaks increased during the subsequent periods of the exercise protocol, mainly in the $4^{\text {th }}$ period. These results may be attributed to impaired neuromuscular control caused by muscle fatigue and decreased muscle's ability to slow down body movements during jump landing. ${ }^{29}$ We should point out, that the actual loads and cumulative loading experienced during actual games are likely higher than the ones experienced during this study due to the presence of other competitors and stressors of the game. ${ }^{17}$ Thus, cumulative loading may help partially explain the typical basketball injuries in health athletes.

Previous studies have shown limited level of support provided by ankle brace to restrict range of motion and improve proprioceptive capability after $30 \mathrm{~min}$ from intermittent exercises. ${ }^{13}$ In contrast, our findings demonstrated that ankle brace tested was effective in lowering the increase of the mediolateral GRF in all four 10 min-periods of the exercise protocol. It is important to highlight that prior to the beginning of each period, we made sure the braces were well fitted to the ankles, which is not always the case in real basketball practice, but may have contributed to the prolonged ankle bracing effects herein observed. These results suggesting that athletes should use the ankle bracing continuously throughout the basketball match. Reduced mediolateral GFR with the fatigue can indicate a slower developed moment on the lower limb and such may be less injurious to the ligaments structures. ${ }^{6,26,27}$ More studies are needed for a better understanding of these changes and their relationship to injuries.

Finally, even though this study has considerable strengths there are some limitations. Despite our study was well powered to detect significant main effects and interactions on GRF variables, it is based on small sample size of young men basketball players. Nonetheless, our study is comparable in size to previously reported studies on this topic ${ }^{8,9,11}$. Other important limitations of the present study are that it not included electromyographic and kinematic data which could provide a more comprehensive understanding of the effects of wearing an ankle brace and there were not evaluations during actual basketball games. On the other hand, our basketball-specific fatigue protocol simulated the activity profile similar to actual basketball game ${ }^{17-19}$ as well as the participants' heart rate, perceived exertion level and jump height during the exercise protocol were not different between tested conditions indicating that the alterations observed on GRF were, in fact, due to the use of the ankle brace. Finally, we should point out that the relationship between the magnitude of the effects of ankle bracing on the ground reaction forces observed herein with the occurrence of ankle injuries during the basketball game in real-life remains unknown.

\section{CONCLUSION}

The ankle brace tested was effective in lowering the increase of the mediolateral GRF during all periods of exercise protocol at the intensity of basketball game, without changing the vertical GFR. However, the mechanical loads increased overtime during subsequent periods of the exercise protocol, mainly for landing of jump.

\section{ACKNOWLEDGEMENTS}

We thank the São Paulo Research Foundation (FAPESP: 2010/108868; 2011/15980-5) and National Council for Scientific and Technological Development (CNPq, no. 482418/2009-5) for the financial support.

All authors declare no potential conflict of interest related to this article

AUTHORS' CONTRIBUTIONS: Each author made significant individual contributions to this manuscript. AC designed the study and was responsible for the collection, analysis and interpretation of the data; drafted the first version of the manuscript, reviewed it critically for important intellectual content, and approved the version of the manuscript to be published. MFG assisted in the collection, analysis and interpretation of the data and reviewed the manuscript critically for important intellectual content. ERV drafted the first version of the manuscript, reviewed it critically for important intellectual content, and translated the manuscript into English. AFAN and PVSM assisted in the data collection and review of the manuscript. DB and ACC reviewed the manuscript critically for important intellectual content and approved the final version of the manuscript to be published. MG designed the study, supervised the data collection and analysis, reviewed the manuscript critically for important intellectual content, and approved the final version of the manuscript to be published.

\section{REFERENCES}

1. Fong DT, Hong Y, Chan LK, Yung PS, Chan KM. A systematic review on ankle injury and ankle sprain in sports. Sports Med. 2007;37(1):73-94

2. Randazzo C, Nelson NG, McKenzie LB. Basketball-related injuries in school-aged children and adolescents in 1997-2007. Pediatrics. 2010;126(4):727-33.

3. McGuine TA, Brooks A, Hetzel S. The effect of lace-up ankle braces on injury rates in high school basketball players. Am J Sports Med. 2011;39(9):1840-8.

4. DiStefano $L$, Padua DA, Brown CN, Guskiewicz KM. Lower extremity kinematics and ground reaction forces after prophylactic lace-up ankle bracing. J Athl Train. 2008;43(3):234-1.

5. Dewar RA, Arnold GP, Wang W, Drew TS, Abboud RJ. Comparison of 3 ankle braces in reducing ankle inversion in a basketball rebounding task. Foot (Edinb). 2019;39:129-35.

6. Dewar RA, Arnold GP, Wang W, Drew TS, Abboud RJ. The effects of wearing an Ankle Stabilizing Orthosis (ASO) Ankle Brace on ankle joints kinetics and kinematics during a basketball rebounding task. Foot (Edinb). 2019;40:34-38.
7. Niu W, Feng T, Wang L, Jiang C, Zhang M. Effects of Prophylactic Ankle Supports on Vertical Ground Reaction Force During Landing: A Meta-Analysis. J Sports Sci Med. 2016;15(1):1-10.

8. Castro A, Goethel M, Gáspari A, Crozara L, Gonçalves M. Ankle brace attenuates the medial-lateral ground reaction force during basketball rebound jump. Rev Bras Med Esporte. 2017;23(23):232-6

9. Sacco I, Takahasi H, Vasconcellos A, Suda EY, Bacarin TA, Pereira CS, et al. Influence of ankle devices in the jump and landing biomechanical responses in basketball. Rev Bras Med Esporte. 2004;10(6):448-52.

10. Simpson KJ, Yom JP, Fu YC, Arnett SW, O'Rourke S, Brown CN. Does wearing a prophylactic ankle brace during drop landings affect lower extremity kinematics and ground reaction forces? J Appl Biomech. 2013;29(2):205-13.

11. Cordova ML, Takahashi Y, Kress GM, Brucker JB, Finch AE. Influence of external ankle support on lower extremity joint mechanics during drop landings. J Sport Rehabil. 2010;19(2):136-48.

12. Riemann BL, Schmitz RJ, Gale M, McCaw ST. Effect of ankle taping and bracing on vertical ground reaction forces during drop landings before and after treadmill jogging. J Orthop Sports Phys Ther. 2002;32(12):628-35 
13. Forbes $H$, Thrussell S, Haycock N, Lohkamp M, White M. The effect of prophylactic ankle support during simulated soccer activity. J Sport Rehabil. 2013;22(3):170-6

14. Castro A, Marques NR, Hallal CZ, Gonçalves M. Ankle brace does not influence strenght and functional balance of ankle muscles over an exercise at the intensity of basketball game Rev Bras Educ Fís Esp. 2017;31(1):61-70.

15. Castro A, Crozara LF, Karuka AH, Spinoso DH, Hallal CZ, Marques NR, et al. Efeito da simulação do jogo de basquetebol sobre o pico de torque e razão funcional dos músculos estabilizadores do tornozelo. Rev Bras Ciênc Mov. 2011;19(4):68-76.

16. Rosenbaum D, Kamps N, Bosch K, Thorwesten L, Völker K, Eils E. The influence of external ankle braces on subjective and objective parameters of performance in a sports-related agility course. Knee Surg Sports Traumatol Arthrosc. 2005;13(5):419-25.

17. Stojanović E, Stojiljković N, Scanlan AT, Dalbo VJ, Berkelmans DM, Milanović Z. The Activity Demands and Physiological Responses Encountered During Basketball Match-Play: A Systematic Review. Sports Med. 2018;48(1):111-35.

18. Scanlan A, Dascombe B, Reaburn P. A comparison of the activity demands of elite and sub-elite Australian men's basketball competition. J Sports Sci. 2011;29(11):1153-60.

19. Conte D, Favero TG, Lupo C, Francioni FM, Capranica L, Tessitore A. Time-Motion Analysis of Italian Elite Women's Basketball Games: Individual and Team Analyses. J Strength Cond Res. 2015;29(1):144-50

20. FIBA IBF. Official basketball rules: Basketball rules \& basketball equipment. 2011, 2014 [Acesso em: 21/03/2021]. Disponível em: http://www.fiba.basketball/documents/BasketballEquipment.pdf

21. Borg G. Perceived exertion as an indicator of somatic stress. Scand J Rehabil Med. 1970;2(2):92-8.
22. Winter DA. Biomechanics and motor control of human movement. 2a ed. Waterloo: Wiley-Interscience Publication; 1990.

23. Dias JA, Dal Pupo J, Reis DC, Borges L, Santos SG, Moro ARP, et al. Validity of two methods for estimation of vertical jump height. J Strength Cond Res. 2011;25(7):2034-9.

24. LaRoche DP, Cremin KA, Greenleaf B, Croce RV. Rapid torque development in older female fallers and nonfallers: a comparison across lower-extremity muscles. J Electromyogr Kinesiol. 2010;20(3):482-8.

25. Hopkins WG. Analysis of reliability with a spreadsheet (beta version). [Acesso em: 21/03/2021] Disponível em: http://www.sportsci.org/2015/NalidRely.htm.

26. Podzielny S, Hennig EM. Restriction of foot supination by ankle braces in sudden fall situations. Clin Biomech (Bristol, Avon). 1997;12(4):253-8.

27. Cordova ML, Armstrong CW, Rankin JM, Yeasting RA. Ground reaction forces and EMG activity with ankle bracing during inversion stress. Med Sci Sports Exerc. 1998;30(9):1363-70.

28. Zhang S, Wortley M, Chen Q, Freedman J. Efficacy of an ankle brace with a subtalar locking system in inversion control in dynamic movements. J Orthop Sports Phys Ther. 2009;39(12):875-83.

29. Shaw MY, Gribble PA, Frye JL. Ankle bracing, fatigue, and time to stabilization in collegiate volleyball athletes. J Athl Train. 2008:43(2):164-71.

30. McKay GD, Goldie PA, Payne WR, Oakes BW. Ankle injuries in basketball: injury rate and risk factors. Br J Sports Med. 2001;35(2):103-8.

31. Wilkerson GB, Pinerola JJ, Caturano RW. Invertor vs. evertor peak torque and power deficiencies associated with lateral ankle ligament injury. J Orthop Sports Phys Ther. 1997;26(2):78-86.

32. Duarte M, Freitas SM. Revision of posturography based on force plate for balance evaluation. Rev Bras Fisioter. 2010;14(3):183-92. 